\title{
Effectiveness and Legitimacy of the Motivational Interviewing With Caregivers on the Oral Health of Special Patients
}

\author{
Eficacia y Legitimidad de la Entrevista Motivacional con los \\ Cuidadores sobre la Salud Oral de Pacientes Especiales
}

\begin{abstract}
Jéssica Silva Peixoto Bem ${ }^{1}$; Deyse Camilla Gomes dos Santos²; Maria Goretti de Lima²; Lidiane Jacinto do Nascimento; Samuel Rodrigo de Andrade Veras²; Bruna Yasmin de Brito Silva ${ }^{2}$ \& Verônica Maria da Rocha Kozmhinsky²
\end{abstract}

BEM, J. S. P.; DOS SANTOS, D. C. G.; DE LIMA, M. G.; DO NASCIMENTO, L. J.; VERAS, S. R. A.; SILVA, B. Y. B. \& KOZMHINSKY, V. M. R. Effectiveness and legitimacy of the motivational interviewing with caregivers on the oral health of special patients. Int. J. Odontostomat., 15(2):466-472, 2021.

ABSTRACT: Difficulty of caregivers in performing oral hygiene for Patients with Special Needs, usually leads to demotivation and negligence. In order to adhere to healthy habits, an intervention model was created: Motivational Interview (MI). It consists of a collaborative conversation to strengthen motivation and commitment to change. Objective: To evaluate the effectiveness and legitimacy of $\mathrm{Ml}$ in a single session on the oral health of children with special needs, unable to perform their hygiene. Methods: Exploratory study with paired randomization, double-blind, including caregivers of patients aged 2 to 19 years treated at the Physical and Motor Rehabilitation Center of IMIP/Recife-Brazil. Caregivers were allocated to a test (Motivational Interview) or control (Traditional Counseling) group. In to, they answered questionnaires, and the child's dental chart and Visible Plaque Index (VPI) were filled. MI group participated in a $10 \mathrm{~min}$ Motivational Interview involving guidance on brushing techniques and making mouth openers. TC group attended a lecture addressing the same theme. In t1, questionnaires were reapplied, followed by a new VPI and dental chart, in addition to a satisfaction survey regarding the methodology used. Results: After 30 days, the Ml group showed a decrease in VPI when comparing the medians (14.70 vs. 10.71) and an increase in the frequency of daily brushing to $03 x$ or more ( $44.4 \%$ vs. $77.8 \%$ ), while the TC group remained practically stable ( 8.75 vs. 10.71 and 28.6 ), but with no statistically significant difference between groups $(p=5 \%)$. Both legitimized the workshop as a pleasurable activity $(100 \%)$ and felt motivated after completion (TC $=85.7 \%, \mathrm{MI}=100 \%)$. Conclusion: A single session of $\mathrm{Ml}$ reduced VPI from disabled children, however, without proving to be more effective than Traditional Counseling.

KEY WORDS: motivational interviewing, oral health, preventive dentistry, people with disabilities.

\section{INTRODUCTION}

An important conditioning factor of an individual's health status is his lifestyle (Antonovsky, 1987). In this sense, activities involving health promotion and disease prevention are essential for the implementation and maintenance of healthy behaviors and adherence to therapeutic plans. However, such adherence is not restricted to compliance with recommendations arising from a directive and responsible approach by the health professional. Thus, according to Silva (2013), it is necessary to offer subsidies for change, considering the individual's cultural, economic, and social reality.
Motivational Interviewing (MI, motivational enhancement therapy) is a "style of collaborative conversation that aims to strengthen the client's motivation and behavior with change" (Figlie \& Guimarães, 2014). William Miller first proposed it in 1983, and its fundamental principles were described by Miller and Rollnick (Miller \& Rollnick, 1994). Initially used to assist alcoholics, this technique has been applied in several contexts in the health area, including Dentistry. The objective of MI is to modify a risky behavior through the readiness to change and resolve

\footnotetext{
${ }^{1}$ Ribeirão Preto School of Dentistry, University of São Paulo, Ribeirão Preto, São Paulo, Brazil.

2 Department of Dentistry, Institute of Integral Medicine Professor Fernando Figueira, Recife, Pernambuco, Brazil.
} 
BEM, J. S. P.; DOS SANTOS, D. C. G.; DE LIMA, M. G.; DO NASCIMENTO, L. J.; VERAS, S. R. A.; SILVA, B. Y. B. \& KOZMHINSKY, V. M. R. Effectiveness and legitimacy of the motivational interviewing with caregivers on the oral health of special patients. Int. J. Odontostomat., 15(2):466-472, 2021.

patients' ambivalence (Figlie \& Guimarães, 2014; Andretta et al., 2014).

This therapy strategies can be synthesized on the acronym OARS (Open Questions-AffirmationPositive Reinforcement-Reflections) in a 2: 1 relationship, that is, two strategies for each open question which are not suitable for short and straightforward answers (Miller \& Rollnick, 2013; Figlie et al., 2015). MI is accessible and can be used by any trained professional through short courses (Gao et al., 2013). It is advantageous when applied in places with high demand for care and little time available since it was designed to be a brief intervention and can occur in a single session, individually or in a group (Gao et al., 2012; Figlie \& Guimarães). However, increasing the number of sessions increases the probability of obtaining a more significant impact of MI on the interviewees (Rubak et al., 2005; Dias et al., 2010).

Weinstein et al. (2004) were the first to use this technique in Pediatric Dentistry to compare the effectiveness of MI with traditional counseling (video + pamphlet) in the development of preventive habits with mothers of children at high risk of caries. One year after the intervention, the test group had, on average, 0.71 new caries lesions, while the control group had 1.91. Thus, MI has proved to be a promising tool for counseling parents and preventing caries disease in children.

In a study by Godard et al. (2011) to assess oral hygiene, patients were divided into traditional prevention and $\mathrm{Ml}$-based prevention group. Patients in the $\mathrm{Ml}$ group showed an improvement of $21+-20$ $\%$ to the detriment of the control group with $4=-5 \%$ $(p<0.001)$, in addition to being more satisfied indicating the positive influence of the Motivational Interviewing on adherence to health promotion and supportive therapies.

Findings of this type are essential since, for patients with special needs, this condition worsens due to the dependence on caregivers whose difficulty in performing oral hygiene can lead to demotivation and negligence. In this sense, the objective was to evaluate the effectiveness and legitimacy of the Motivational Interviewing with caregivers about the attitude and habits related to the oral health of children and adolescents with special needs who are unable to perform their hygiene when compared to Traditional Counseling.

\section{MATERIAL AND METHOD}

The project was carried out following Resolution 466/12 of the National Commission for Ethics in Research (CONEP), after due approval by the Research Ethics Committee of the Institute of Integral Medicine Prof. Fernando Figueira (IMIP) under CAAE $n^{\circ}$. 17714619.2.0000.5201 and opinion no. 3.538.299. This work was a randomized, double-blind, exploratory, and prospective clinical study carried out between October and December 2019 at the Physical and Motor Rehabilitation Center of the Institute of Integral Medicine Prof. Fernando Figueira (IMIP), Recife, Pernambuco, Brazil.

The study population consisted of caregivers of patients aged 2 to 19 years with special needs whose physical, intellectual, or multiple disabilities make it impossible to perform their oral hygiene. Caregivers were excluded from the research: those who presented some degree of intellectual disability or mental disorder, or with whom it was not possible to make telephone contact or those who did not attend the workshops after two appointments.

Once they met the eligibility criteria, caregivers had the nature of the research, and its stages explained, and they were invited to sign the Informed Consent Form. If the participant agreed, a standardized questionnaire was applied, elaborated according to the study variables. The questions included sociodemographic data, knowledge about oral hygiene, beliefs and attitudes, and brushing habits. That done, the caregiver was included in a database and waited for post-randomized telephone contact to schedule the workshop.

Caregivers were randomly assigned employing paired randomization, according to the day of the week that the children/adolescents had consultations at the Rehabilitation Center. Caregivers who have to be at the Rehabilitation Center on the same day of the week were allocated in pairs and then separated by lot in a test (MI) and control (TC) group. The first participated in a single 10-minute Motivational Interview session involving guidance on brushing and hands-on techniques for making mouth openers (Fig. 1). For the second group, Traditional Counseling, there was a lecture on the same topic.

The interventions took place in a reserved room at the Dental Clinic, and the appointment was made 
BEM, J. S. P.; DOS SANTOS, D. C. G.; DE LIMA, M. G.; DO NASCIMENTO, L. J.; VERAS, S. R. A.; SILVA, B. Y. B. \& KOZMHINSKY, V. M. R. Effectiveness and legitimacy of the motivational interviewing with caregivers on the oral health of special patients. Int. J. Odontostomat., 15(2):466-472, 2021.

on days of the week that coincided with the child's consultations at the hospital. On the scheduled date, before the beginning of the workshop, the dental chart was performed by a single evaluator with the help of mirror $n^{\circ} 5$ under natural light, in which the teeth present in the oral cavity were noted followed by visualization of plaque to calculate the initial Visible Plaque Index (VPI).

Thirty days after the intervention, the questionnaire was reapplied, followed by a clinical reassessment (VPI and dental chart) of the child by the same evaluator, in addition to a satisfaction survey regarding the workshops and methodology used.

Data were analyzed descriptively through absolute and percentage frequencies for categorical variables and measures: mean, standard deviation, minimum value, $\mathrm{P} 25$, median, $\mathrm{P} 75$, and maximum value for numerical variables. Fisher's Exact Test assessed differences between groups for categorical variables and t-Student test with equal variances for the numerical variable (VPI). When comparing the evaluations in each group in the numerical variable, the paired t-Student test was used.

Those tests were chosen due to the verification of the normality of the data. The Shapiro-Wilk test performed the verification of normality, and the Levene $\mathrm{F}$ test performed the equality of variances. The margin of error used in deciding the statistical tests was $5 \%$.

It is noteworthy that, as recommended in studies that use Motivational Interviewing, the researcher took a theoretical-practical course with certification and a duration of 20 hours, specifically for the application of this technique.

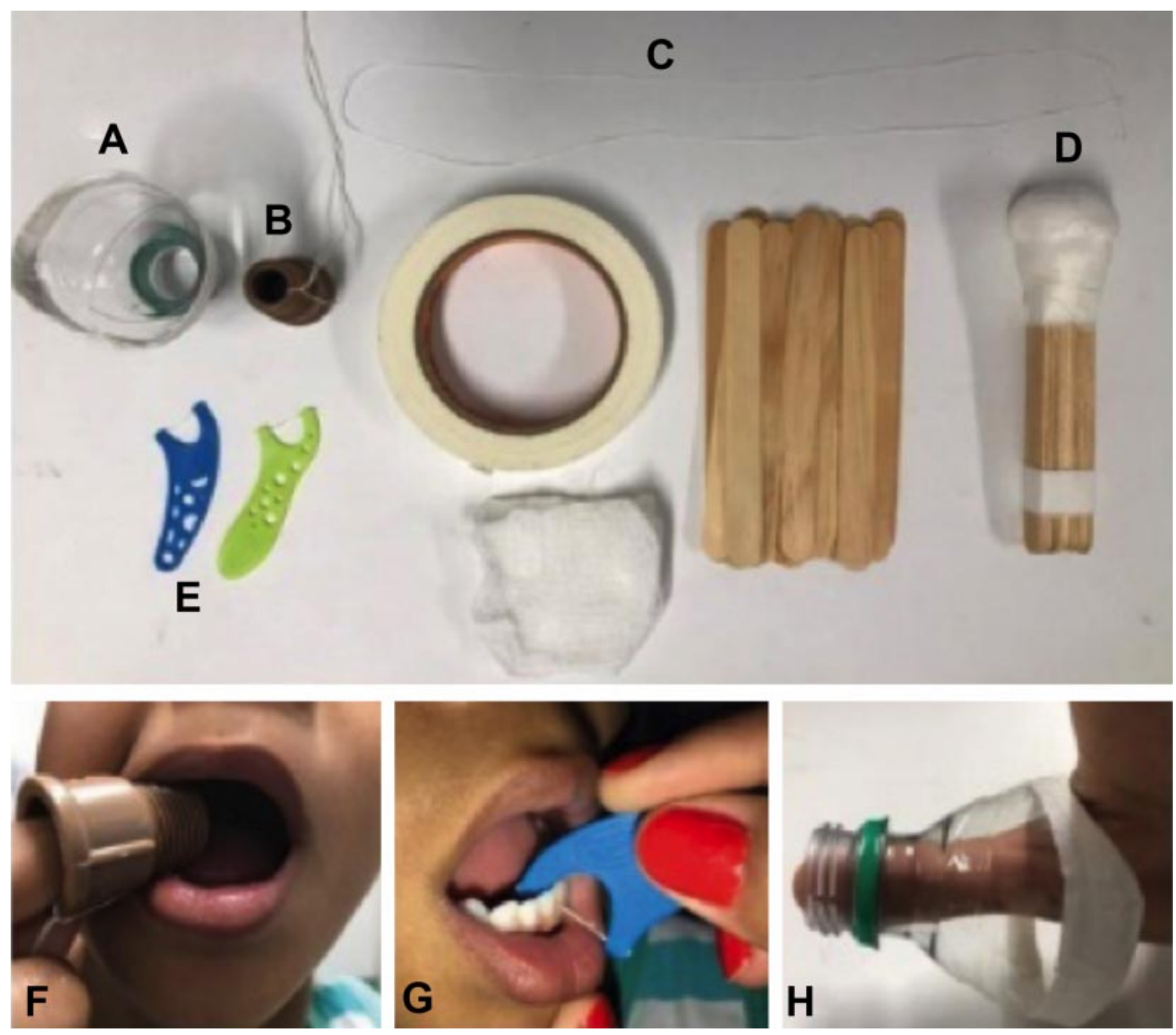

Fig. 1. A. "PET bottle" opener, B. "pipe glove" opener, C. floss, D. "gauze doll" opener, E. dental floss palette, F. "pipe glove" in use, G. floss palette in use, H."PET bottle" opener in demonstration of use. 
BEM, J. S. P.; DOS SANTOS, D. C. G.; DE LIMA, M. G.; DO NASCIMENTO, L. J.; VERAS, S. R. A.; SILVA, B. Y. B. \& KOZMHINSKY, V. M. R. Effectiveness and legitimacy of the motivational interviewing with caregivers on the oral health of special patients. Int. J. Odontostomat., 15(2):466-472, 2021.

\section{RESULTS}

From the initial population of 34 caregivers, 16 caregivers were considered for the final analysis of this study (test group $=09$ and control $=07$ ). The others were excluded because they did not show up after two appointments for the first intervention $(n=13)$, phone to contact was unavailable $(n=02)$, and due to withdrawal because of illness of the child $(n=02)$ or the caregiver $(n=01)$.

Regarding the profile of children, the majority of the group were girls $(71.4 \%)$, while boys prevailed in the $\mathrm{MI}$ group ( $77.8 \%$ ). A varied age range from 02 to 08 years old, with the frequency of children up to 03 years old slightly higher in both groups (TC $=57.1 \%$, $\mathrm{MI}=55.6 \%$ ). The underlying diseases present in both groups were Hydrocephalus, Microcephaly, Zika Virus Microcephaly, Myelomelingocele, and Cerebral Palsy. For a fixed margin of error (5\%), no significant differences were recorded between the two groups for any variation.

As for the caregiver's profile, it was found that except for one caregiver in each group, the other caregivers were the children's mothers. In the TC group, the age group of caregivers from 20 to 29 years old was the most frequent $(71.4 \%)$, while in the MI group, the majority $(77.8 \%)$ was between 30 and 41 years old. Asked if they had already taken the child to the dentist, 4 caregivers responded positively in the TC group and 5 in the Ml group. Only one TC group participant stated episodes of denial of dental care due to the child's health condition. There were no differences between the two groups for any of the variables analyzed.
As for oral hygiene habits, concerning brushing frequency, in the Ml group, there was an increase from $4(44.4 \%)$ to $7(77.8 \%)$ for children who had their teeth brushed $03 \mathrm{x}$ a day, while the TC group maintained stable. Noteworthy is the increase in the use of artifices to facilitate oral hygiene in both groups. Group TC increased $0(0 \%)$ to $3(42.9 \%)$ while group MI, $0(0 \%)$ to $5(55.6 \%)$. The "pipe glove" was the item of preference for both groups. All parents were aware of the etiology of caries and the influence of diet on the course of caries disease. They also already believed that oral health interferes with the child's general health, and this was pointed out as a motivation for care. After the workshop, there was a slight decrease in the amount of toothpaste used in both groups.

Regarding the Visible Plaque Index, there was no significant difference between the groups, as seen in Table I. However, the MI group showed a slight decrease when comparing the pre and postintervention medians (14.7 vs. 10.71) while the TC group remained practically stable (8.75 vs. 8.92$)$.

Regarding satisfaction with the workshops, all participants agreed with the statements: "I found the workshop to be a pleasant activity, and I enjoyed participating" also, "I believe that the workshop should be a frequent practice at IMIP." Except for one participant in the TC group who attributed less than 5 points in the statement, "After the workshop, I felt motivated to take care of the child's oral health", the others in both groups attributed 5 points. There were no significant differences in the items covered.

Table I. VPI according to evaluation per group. IMIP, Recife-PE, Brazil, 2020.

\begin{tabular}{|c|c|c|c|c|}
\hline \multirow[b]{2}{*}{ VPI } & \multicolumn{2}{|c|}{ Group $^{(1)}$} & \multirow[b]{2}{*}{ Group Total } & \multirow[b]{2}{*}{$p$ value } \\
\hline & TC & Ml & & \\
\hline & $\begin{array}{c}\text { Mean } \pm \text { DP } \\
\text { Median (P25; P75) }\end{array}$ & $\begin{array}{c}\text { Mean } \pm \text { DP } \\
\text { Me dian (P25; P75) }\end{array}$ & $\begin{array}{c}\text { Mean } \pm \text { DP } \\
\text { Median (P25; P75) }\end{array}$ & \\
\hline Before & $\begin{array}{c}13,03 \pm 9,28 \\
8,75(5,55 ; 17,50)\end{array}$ & $\begin{array}{c}16,66 \pm 13,10 \\
14,70(6,25 ; 23,75)\end{array}$ & $\begin{array}{c}15,07 \pm 11,38 \\
14,00(6,04 ; 18,44)\end{array}$ & $p^{(2)}=0,545$ \\
\hline After & $\begin{array}{c}11,07 \pm 11,35 \\
8,92(1,25 ; 18,75)\end{array}$ & $\begin{array}{c}15,76 \pm 12,89 \\
10,71(5,63 ; 30,18)\end{array}$ & $\begin{array}{c}13,71 \pm 12,08 \\
10,50(2,19 ; 24,64)\end{array}$ & $\mathrm{p}^{(2)}=0,461$ \\
\hline$p$ value & $p^{(3)}=0,620$ & $\mathrm{p}^{(3)}=0,697$ & $p^{(3)}=0,504$ & \\
\hline
\end{tabular}

$\left(^{\star}\right)$ Significant difference at value 5,0\%. (1) Group: TC = Tradicional Counseling; Ml = Motivational Interviewing. (2) t-Student test with equal variances . (3) t-Student test for paired samples 


\section{DISCUSSION}

The difficulty in performing oral hygiene for children with special needs is a recurring complaint from caregivers during consultations. Such difficulty leads to the reduction or abandonment of oral health care, triggering the development of periodontal disease and caries. Besides, dental consultation time is short for performing necessary therapeutic procedures and ensuring awareness of behavior change. In addition, usually in these consultations, traditional advice is given, and, for Kapoor et al. (2019), in this type of counseling, the professional offers both information and solutions to patients' problems. This approach disregards the social determinants of health that so much interfere with human behavior. In this approach, patients may consider advice to be critical and meddling, leading to resistance to change.

The Motivational Interview has stood out for this purpose for being based on internal motivation based on strategies that elucidate self-motivation affirmations of the interviewee while avoiding those that refer to resistant behaviors (Jamieson et al., 2020).

In a systematic review by Morton et al. (2015), the sample sizes ranged from less than 50 participants to more than 1000. Most studies either divided the participants equally in terms of gender or had a majority of women, coinciding with the findings for caregivers of this study.

As for the frequency of brushing, there was an increase pre- and post-intervention in the MI group for the number of children who had their teeth brushed $03 x /$ day. Similar results were also exposed by Menegaz et al. (2020), whose work indicated an increase in the brushing frequency of $02 x$ or more with an absolute difference of $30.5 \%$ for the MI group. In a randomized clinical trial on the influence of $\mathrm{MI}$ in preventing early childhood caries involving 1065 children and their caregivers, there was no significant difference between group interaction versus time for brushing frequency. However, there was a significant increase for brushing $02 x$ or more / day for both groups when comparing the initial period and after 12 months (odds ratio $=2.76$ ) and between 12 and 24 months (odds ratio $=1.39)($ Henshaw et al., 2018).

The present study was not able to analyze the influence of the Motivational Interview on the control of caries disease concerning the appearance of new injuries since the study period was short (30 days) for the installation and development of visible injuries. Systematic review and meta-analysis carried out by Borrelli et al. (2015), pointed out that studies have shown increased oral hygiene in children whose parents have undergone MI. However, in three studies that also included an analysis of the influence of MI on the number of caries lesions, only two of them had enough information to be included in the analysis. When considering only these studies, there was no significant effect of MI on caries. In contrast, a community trial study published in 2019 associated MI with the reduction of caries injuries in all socioeconomic groups studied, especially in economically vulnerable groups $(p=0.03)$. Also, prevention was seen as more effective in groups with higher caries experience (Faustino-Silva et al., 2019a).

Regarding the presence of bacterial plaque, in their 2014 systematic review, Cascaes et al. (2014) showed no reduction in plaque comparing $\mathrm{Ml}$ and control group in studies with good quality of evidence. However, two studies with quality between "good" and "reasonable" suggested relevance for this variable showing $39 \%$ and $77 \%$ reduction in the percentage in each study. This data corroborates the findings of the present study. A research carried out in Spain analyzed the variation of plaque according to the O'Leary Index, and showed there was a decrease in the index in both groups after 03 months of intervention. However, the decrease was more considerable in the test group (14.8 vs. 10.1), but without a statistically significant difference (Álvarez et al., 2015). Similarly to the present study, the TC group remained practically stable ( 8.75 vs. 8.92$)$. In contrast, the MI group showed a slight decrease in the amount of visible plaque when compared to the pre and postintervention medians (14.7 vs. 10.71).

The fact that the dentist is responsible for conducting the interview would not be a limiting factor for the study as long as the sessions were validated through a verification instrument. In a randomized community study carried out in southern Brazil, the maintenance of fundamental values of the motivational interview in the practice of dentists who received training was evaluated. The revaluations took place after 01 and 02 years using three different validation instruments. In both times, an improvement was 
maintained in the answers with a statistically significant difference $(p<0.01)$ for the use of open questions, reflective listening, and a total percentage of correct answers in the tests. This result suggests that even a short course (08 hours) is capable of training dentists to act in accordance with the spirit and technique of MI (Faustino-Silva et al., 2019b).

For Morton et al. studies should include continuous assessments to determine the professionals' competence during the interviews and whether patients are receiving the intervention as they should. Most studies in its systematic review did not include fidelity tests. The same occurred in the review carried out by Martins et al. (2009), in which a verification instrument validated only 02 of the 04 studies involving oral health within the 37 articles analyzed. This absence can interfere with the internal validation of studies and the interpretation of findings in studies involving MI.

Nevertheless, $\mathrm{Ml}$ is still considered a promising strategy for promoting health and changing habits, and it can be applied on a community scale or as a government strategy. Jamieson et al. highlighted that, as it is a type of psychotherapy that respects culture and individuality, it is more likely to be accepted in more resistant groups. In this work, both groups legitimized the actions promoted on workshops and endorsed the need for their perpetuation.

According to the results of this study, it can be concluded that single Motivational Interview session with caregivers reduced the Visible Plaque Index of children with special needs, but with no statistically significant effect when compared to traditional counseling. Although $\mathrm{MI}$ is considered a promising strategy to promote oral health care, other clinical trials using validation instruments are necessary to ensure the correct application of the technique and promote reliability to the results.

Also, the size of the samples must be considered since, because they are children with systemic and locomotion impairment, losses and abstentions impacted the final quantity and may have an influence on detecting the effect of the interventions. Other long-term studies with pediatric patients are necessary, relating Ml not only to the control of caries lesions but also to the presence of plaque as an indicator for oral health, since it consists of an etiological factor of caries and periodontal disease.
BEM, J. S. P.; DOS SANTOS, D. C. G.; DE LIMA, M. G.; DO NASCIMENTO, L. J.; VERAS, S. R. A.; SILVA, B. Y. B. \& KOZMHINSKY, V. M. R. Eficacia y legitimidad de la entrevista motivacional con los cuidadores sobre la salud oral de pacientes especiales. Int. J. Odontostomat., 15(2):466-472, 2021.

RESUMEN: La dificultad de los cuidadores para realizar la higiene oral en pacientes con necesidades especiales, generalmente conduce a la desmotivación y negligencia. Con el objetivo de adherirse a los hábitos saludables, se creó un modelo de intervención a partir de una conversación colaborativa: Entrevista Motivacional (EM). El objetivo de este trabajo fue evaluar la eficacia y la legitimidad de la EM en la salud oral para los PNE infantiles. Estudio exploratorio con aleatorización pareada, doble ciego, que incluye cuidadores de pacientes de 2 a 19 años tratados en el Centro de Rehabilitación Física y Motora del IMIP/RecifeBrasil. Los cuidadores fueron asignados en dos grupos: prueba (Entrevista Motivacional - EM) y control (Consejería Tradicional - CT). En t0, se respondieron los cuestionarios y se realizó el Odontograma y el Índice de Placa Visible (IPV) del niño. Grupo EM participó en una entrevista motivacional de 10 minutos que incluyó orientación sobre las técnicas de cepillado y la apertura de la cavidad oral. Grupo CT asistió a una conferencia sobre el mismo tema. En t1, se volvieron a aplicar los cuestionarios, seguidos de una nueva IPV y un odontograma, además de una encuesta de satisfacción sobre la metodología utilizada. Después de 30 días, el grupo EM mostró una disminución en IPV al comparar las medianas $(14,70$ vs. 10,71$)$ y un aumento en la frecuencia diaria de cepillado a $03 x$ o más $(44,4 \%$ vs. $77,8 \%)$, mientras que el grupo CT permaneció prácticamente estable ( 8,75 vs. 8,92 y $28,6)$, pero sin diferencias estadísticamente significativas entre los grupos ( $p=5 \%$ ). Ambos legitimaron el taller como una actividad placentera (100 \%) y se sintieron motivados después de la finalización (AT $=85,7 \%, E M=100 \%$ ). Una sola sesión de EM redujo la IPV de las PNE, sin demostrar que es más efectiva que la asesoría tradicional.

PALABRAS CLAVE: entrevista motivacional, salud bucal, odontología preventiva, personas con discapacidad.

\section{REFERENCES}

Álvarez, A. B.; Yahne, C. E.; Nosàs, M.; Boj, J. R. \& Espasa, E. Effects of motivational interviewing on the oral health of pediatric patients. Odontol. Pediatr., 23(3):187-203, 2015.

Andretta, I.; Meyer, E.; Kuhn, R. P. \& Rigon, M. A entrevista motivacional no Brasil: uma revisão sistemática. Psicol. Saúde, 22(2):15-21, 2014.

Antonovsky, A. Unraveling the Mystery of Health: How People Manage Stress and Stay Well. São Francisco, Jossey-Bass, 1987.

Borrelli, B.; Tooley, E. M. \& Scott-Sheldon, L. A. Motivational interviewing for parent-child health interventions: a systematic review and meta-analysis. Pediatr. Dent., 37(3):254-65, 2015. 
Cascaes, A. M.; Bielemann, R. M.; Clark, V. L. \& Barros, A. J. D. Effectiveness of motivational interviewing at improving oral health: a systematic review. Rev. Saúde Pública, 48(1):142-53, 2014.

Dias, R. B.; Nonato, S. M. \& Chaves, S. R. Mudança comportamental e de hábitos de vida dos clientes participantes nos programas de gerenciamento de condições crônicas. In: Inovação e prática no gerenciamento de condições crônicas: Implantando o modelo cuidador da Federação das Unimeds de Minas Gerais. Belo Horizonte (MG), Unimed MG, 2010.

Faustino-Silva, D. D.; Colvara, B. C.; Meyer, E.; Hugo, F. N.; Celeste, R. K. \& Hilgert, J. B. Motivational interviewing effects on caries prevention in children differ by income: A randomized cluster trial. Community Dent. Oral Epidemiol., 47(6):477-84, 2019a.

Faustino-Silva, D. D.; Meyer, E.; Hugo, F. N. \& Hilgert, J. B. Effectiveness of motivational interviewing training for primary care dentists and dental health technicians: results from a community clinical trial. J. Dent. Educ., 83(5):585-94, 2019b.

Figlie, N. B. \& Guimarães, L. P. A Entrevista motivacional: conversas sobre mudanças. Bol. Acad. Paul. Psicol., 34(87):472-89, 2014

Figlie, N. B.; Guimarães, L. P.; Bordin, S. \& Laranjeira, R. Entrevista Motivacional. In: Aconselhamento em Dependência Química. São Paulo, Grupo Gen, 2015.

Gao, X.; Lo, E. C. M. \& Chan, C. Motivational interviewing for changing oral health behaviours of adolescents. J. Dent. Res., 91(Spec. Issue C):169376, 2012.

Gao, X.; Lo, E. C.; McGrath, C. \& Ho, S. M. Innovative interventions to promote positive dental health behaviors and prevent dental caries in preschool children: study protocol for a randomized controlled trial. Trials, 14:118, 2013.

Godard, A.; Dufour, T. \& Jeanne, S. Application of selfregulation theory and motivational interview for improving oral hygiene: a randomized controlled trial. J. Clin. Periodontol., 38(12):1099-105, 2011.

Henshaw, M. M.; Borrelli, B.; Gregorich, S. E.; Heaton, B.; Tooley, E. M.; Santo, W.; Cheng, N. F.; Rasmussen, M.; Helman, S.; Shain, S.; et al. Randomized Trial of Motivational Interviewing to Prevent Early Childhood Caries in Public Housing. J. D. R. Clin. Trans. Res., 3(4):353-65, 2018.

Jamieson, L. M.; Garcia, R. I.; Sohn, W. \& Albino, J. Challenges and solutions for improved oral health: examples from motivational interviewing trials. J. D. R. Clin. Trans. Res., 5(2):107-108, 2020.

Kapoor, V.; Gupta, A. \& Arya, V. Behavioral changes after motivational interviewing versus traditional dental health education in parents of children with high caries risk: 1-year study. J. Indian Soc. Pedod. Prev. Dent., 37(2):192-7, 2019.

Martins, R. K. \& McNeil, D. W. Review of motivational interviewing in promoting health behaviors. Clin. Psychol. Ver., 29(4):283-9, 2009.

Menegaz, A. M.; Quevedo, L. A.; Muniz, L. C.; Finlayson, T. L.; Ayala, G. X. \& Cascaes, A. M. Changes in young children's oral healthrelated behaviours and caregiver knowledge: A cluster randomized controlled trial in Brazil. Community Dent. Oral Epidemiol., 48(1):81-7, 2020.

Miller, W. R. \& Rollnick, S. Motivational Interview: Helping People Change. New York, The Guilford Press, 2013.

Miller, W. R. \& Rollnick, S. Motivational interviewing - preparing people to change addictive behavior. Int. J. Soc. Psychiatry, 40(3):230, 1994.

Morton, K.; Beauchamp, M.; Prothero, A.; Joyce, L.; Saunders, L.; Spencer-Bowdage, S.; Dancy, B. \& Pedlar, C. The effectiveness of motivational interviewing for health behaviour change in primary care settings: a systematic review. Health Psychol. Rev., 9(2):205-23, 2015.

Rubak, S.; Sandbaek, A.; Lauritzen, T. \& Christensen, B. Motivational interviewing: a systematic review and meta-analysis. Br. J. Gen. Pract., 55(513):305-12, 2005.
Silva, E.S. O uso da técnica da Entrevista Motivacional como estratégia para adesão do paciente ao cuidado da saúde periodontal. Piracicaba, Faculdade de Odontologia de Piracicaba/ Universidade Estadual de Campinas, 2013.

Weinstein, P.; Harrison, R. \& Benton, T. Motivating parents to prevent caries in their young children: one-year findings. J. Am. Dent. Assoc., 135(6):731-8, 2004.

Corresponding author:

Jessica Silva Peixoto Bem

957 Adalberto Pajuaba St., C-14

Sumarezinho

Ribeirão Preto - SP

BRAZIL

E-mail: jessicaspbem@usp.br 